\title{
Content analysis of Hydrometeorological Network in the Lower Benue River Basin, Nigeria.
}

\section{TEMI E. OLOGUNORISA}

\author{
Centre for Climate Change and Environmental Research, \\ Osun State University, \\ E-mail (ologunorisatemi@yahoo.com)
}

\begin{abstract}
This study deals with content analysis of hydrometerological networks in the Lower Benue River Basin, Nigeria. This is with the overall aim of determining the effectiveness of the network in terms of providing useful data for agricultural planning. The study examines the type of stations in the river basin, the type of equipment available in each station, the frequency of observation, and the range of weather elements measured as well as the utilitarian value of the networks for agricultural research and environmental panning and management. To realize this, a total of 30 out of 48 hydrometerological stations in the river basin were analyzed. The results of the analysis show among other things that, complete data were very hard to come by, and so much interpolation had to be done. Thus important hydrometerological information relevant to agricultural planning are missing. Also that the existing spatial distribution of the networks has been found to be highly inadequate in some parts of the river basin. Finally, only the synoptic stations have little relevance of agricultural production. The study concludes by recommending a wide range of measures to improve the quality of the networks to ensure sustainable agricultural production and planning in the region. @ JASEM
\end{abstract}

A hydro-meteorological networks is defined as a set of stations at which observations of hydrologic phenomena are made as a function of time, and they are meant to provide information to aid in planning, management and decision making (Dawdy, 1979). A hydro-meteorological network consist not only of the stations where data are collected but also the analytical models for extrapolating and interpolating data in time and space (Oguntoyinbo, 1987). Hydrological data encompasses all data commonly used by the hydrologist, and the data are not necessarily of a hydrological nature nor need be collected by an hydrological agency (WMO, 1957). They include data on precipitation, stream flow and river lake stage, ground water levels, water infiltration and soil moisture. Others are sediment, transportation and deposition, water quality, evaporation and evapotranspiration, snow pack, frost penetration, soil temperature, interception and depression storage. Another set of data are often collected include topography, river profile and cross section, subterranean characteristics, soil types and vegetation cover. Others in this second group include water temperature, air temperature, radiation, wind and humidity.

Different types of observatories exist for monitoring these phenomena and are graded according to the types of observations made, frequency of observation and the status of the observer (Ayoade, 1998). Such stations include synoptic weather station, agro-meteorological station, climatic station, hydro-meteorological and rainfall stations.

It has been observed that majority of the studies carried out on content analysis of hydrometeorological networks are restricted to the technologically advanced countries (Catteral, 1972; Cisleriora, et al 1974; Dawdy, 1979; Dawdy, et al
1972; Eagleson, 1967; Hendrick et al 1970; Hershfield, 1967; Hutchinson, 1967; Kreuder, 1979; Osborn et al 1965, Osborn et al 1979; Shaw et al 1976; and Stol, 1972). The conclusion from these studies is that most stations in developed countries are use specific, and they have strategies which reduce political consideration and interagency conflicts.

Only a few studies have been reported for the tropics (Oguntoyinbo, 1987). The few available studies showed that most of the existing stations are not in their proper location, and their locations have been influenced more by political considerations and without consideration to how representative they are to the surrounding area in question and their relationship to existing stations. Although the World Meteorological Organisation (1965) has made its recommendation for the number of rainguages needed in certain areas, research has shown that modifications are necessary due to various local reasons. In assessing the content of hydro-meteorological networks therefore, the existing hydro-meteorological network would be audited to find how effective and efficient are they. It is in this respect that this study deals with the content analysis of hydrometeorological network in the Lower Benue River Basin, Nigeria in order to assess the utilitarian value of the networks for agricultural research, planning and enhanced food production.

\section{METHODOLOGY}

A total of 30 hydro-meteorological stations in the Lower Benue River Basin were visited. At all the stations visited, personal observations were made of all available equipment. Auditing of the stations were carried out in all the stations visited to determine the actual location of the stations, frequency of measurement at each hydro- 
meteorological station, reason why the stations were established, year of establishment of the stations, and how much of their objectives have been met, the quality of instruments and maintenance facilities, qualification of the observatory staff and the frequency of supply of recording materials.
Also on the spot reading were made to compare readings with available records in order to test for consistency. The stations' workers were also interviewed and their and their responses were utilized to form part of the primary data for this study.

Table 1: Meteorological Stations and the Equipment available in the Lower Benue River Basin Development Authority.

\begin{tabular}{|c|c|c|c|c|c|c|}
\hline S/no & Station & Temp & Rainfall & Evaporation & Wind speed & Isolation \\
\hline 1. & Agogo & & $*$ & & & \\
\hline 2. & Akwanga & & * & $*$ & $*$ & \\
\hline 3. & Ankpa & $*$ & * & & & \\
\hline 4. & Ashige & & $*$ & & & \\
\hline 5. & Ayanga & & * & & & \\
\hline 6. & Dep & $*$ & $*$ & & & \\
\hline 7. & Longkat & * & * & & & \\
\hline 8. & Makurdi & $*$ & $*$ & $*$ & $*$ & $*$ \\
\hline 9. & Katsin-ala & $*$ & $*$ & $*$ & $*$ & $*$ \\
\hline 10. & Okete & & * & & & \\
\hline 11. & Doma & $*$ & $*$ & $*$ & $*$ & $*$ \\
\hline 12. & Bokkos & $*$ & $*$ & $*$ & $*$ & \\
\hline 13. & Heipang (jos) & $*$ & $*$ & $*$ & $*$ & $*$ \\
\hline
\end{tabular}

\begin{tabular}{|c|c|c|c|c|}
\hline S/no & River & Station & Latitude & Longitude \\
\hline 1. & Akwenyi & Ouyondu & $8^{0} .34^{1} .40^{\prime \prime}$ & $8^{0} .55^{1} .15^{\prime \prime}$ \\
\hline 2. & Arikya & Arika & $8^{0} .49^{1} .50^{\prime \prime}$ & $7^{0} .40^{1} .30^{\prime \prime}$ \\
\hline 3. & Arikya & Kiguna & $8^{0} .40^{1} .20^{\prime \prime}$ & $8^{0} .54^{1} .55^{\prime \prime}$ \\
\hline 4. & Ashige & Ashige & $8^{0} .34^{1} .35^{\prime \prime}$ & $8^{0} .48^{1} .40^{\prime \prime}$ \\
\hline 5. & Biku & Buku & $8^{0} .56^{1} .10^{\prime \prime}$ & $8^{0} .31^{1} .20^{\prime \prime}$ \\
\hline 6. & Damsak & Chip damask & $9^{0} .10^{1} .50^{\prime \prime}$ & $9^{0} .22^{1} .40^{\prime \prime}$ \\
\hline 7. & Dep & Gallo & $8^{0} .46^{1} .25 ”$ & $8^{0} .54^{1} .40^{\prime \prime}$ \\
\hline 8. & Dep & Site 1 & $8^{0} .37^{1} .05^{\prime \prime}$ & $8^{0} .57^{1} .30^{\prime \prime}$ \\
\hline 9. & Farin ruwa & Mutu & $8^{0} .57^{1} .30^{\prime \prime}$ & $8^{0} .53^{1} .10^{\prime \prime}$ \\
\hline 10. & Gwalang & Chip west & $9^{0} .11^{1} .30^{\prime \prime}$ & $9^{0} .22^{1} .30^{\prime \prime}$ \\
\hline 11. & Gwayaka & Alligani & $8^{0} .43^{1} .20^{\prime \prime}$ & $8^{0} .49^{1} .30^{\prime \prime}$ \\
\hline 12. & Keoloeng & Gidda lifidi & $9^{0} .03^{1} .05^{\prime \prime}$ & $8^{0} .22^{1} .05^{\prime \prime}$ \\
\hline 13. & Mada & Tede 1 & $9^{0} .00^{1} .28^{\prime \prime}$ & $8^{0} .13^{1} .50^{\prime \prime}$ \\
\hline 14. & Mada & Tede 2 & $9^{0} .53^{1} .28^{\prime \prime}$ & $8^{0} .19^{1} .50^{\prime \prime}$ \\
\hline 15. & Geina & Dma di & $8^{0} .53^{1} .00^{\prime \prime}$ & $8^{0} .19^{1} .50^{\prime \prime}$ \\
\hline 16. & Geina & Doma d8 & $8^{0} .21^{1} .00^{\prime \prime}$ & $8^{0} .15^{1} .00^{\prime \prime}$ \\
\hline 17. & Shemankar & Dokan tofa & $9^{0} .03^{1} .00^{\prime \prime}$ & $9^{0} .19^{1} .00^{\prime \prime}$ \\
\hline 18. & Shemankar & Randa & $9^{0} .11^{1} .50^{\prime \prime}$ & $9^{0} .19^{1} .45^{\prime \prime}$ \\
\hline 19. & Shendan & Shendan & $8^{0} .53^{1} .10^{\prime \prime}$ & $9^{0} .25^{1} .05^{\prime \prime}$ \\
\hline 20. & Tan & Ambaka & $8^{0} .56^{1} .25^{\prime \prime}$ & $8^{0} .53^{1} .10^{\prime \prime}$ \\
\hline 21. & Wowen & Women & $8^{0} .51^{1} .00^{\prime \prime}$ & $8^{0} .29^{1} .30^{\prime \prime}$ \\
\hline 22. & Aini & Nassarawa & $8^{0} .13^{1} .40^{\prime \prime}$ & $8^{0} .43^{1} .40^{\prime \prime}$ \\
\hline 23. & Amba & Lafia & $8^{0} .29^{1} .30^{\prime \prime}$ & $8^{0} .30^{1} .05^{\prime \prime}$ \\
\hline 24. & Awonge & B.a.d & $8^{0} .36^{1} .58^{\prime \prime}$ & $8^{0} .21^{1} .00^{\prime \prime}$ \\
\hline 25. & Gbata & Gbata & $8^{0} .56^{1} .10^{\prime \prime}$ & $8^{0} .33^{1} .20^{\prime \prime}$ \\
\hline 26. & Jida & Jida & $8^{0} .51^{1} .00^{\prime \prime}$ & $8^{0} .29^{1} .30^{\prime \prime}$ \\
\hline 27. & Mada & Agam & $8^{0} .06^{1} .00^{\prime \prime}$ & $8^{0} .06^{1} .00^{\prime \prime}$ \\
\hline 28. & Mada & Ginda ayemu & $8^{0} .10^{1} .00^{\prime \prime}$ & $8^{0} .00^{1} .30^{\prime \prime}$ \\
\hline 29. & Mada & Gudi bridge & $9^{0} .02^{1} .40^{\prime \prime}$ & $8^{0} .34^{1} .50^{\prime \prime}$ \\
\hline 30. & Mada & Ogobo & $8^{0} .04^{1} .00^{\prime \prime}$ & $8^{0} .02^{1} .20^{\prime \prime}$ \\
\hline 31. & Mada & Rutu & $8^{0} .25^{1} .50^{\prime \prime}$ & $8^{0} .11^{1} .30^{\prime \prime}$ \\
\hline 32. & Mada & Tede 3 & $9^{0} .02^{1} .40^{\prime \prime}$ & $8^{0} .34^{1} .05^{\prime \prime}$ \\
\hline 33. & Oeonda & Katsina & $8^{0} .13^{1} .00^{\prime \prime}$ & $7^{0} .20^{1} .15 "$ \\
\hline 34. & Wusan & Chip east & $9^{0} .11^{1} .35^{\prime \prime}$ & $9^{0} .23^{1} .10^{\prime \prime}$ \\
\hline 35. & Wulko & Duko & $8^{0} .52^{1} .25^{\prime \prime}$ & $8^{0} .26^{1} .05^{\prime \prime}$ \\
\hline
\end{tabular}

\section{RESULTS AND DISCUSSION}

The hydro-meteorological stations in the study area were established between 1927 and 1983. The frequency of observation was found to be twice daily at 0800 hours (8.00a.m. local time) and 1600 (4.00p.m local time) except the synoptic station at the Makurdi airport where observations were made hourly. Also, complete data was hard to come by and so much interpolation had to be done. In addition, 30 stations visited, interpolation had to be carried out for $93 \%$ of the stations. About $60 \%$ of the stations have missing data. The standard size of an observatory is $20 \times 20 \mathrm{~m}$ but only $15 \%$ of the stations met the requirement. Also, about $20 \%$ of 
the stations were improperly sited. Wind vanes were placed in shades or beside buildings, and many of the rainguages were improperly sited. It was observed that $60 \%$ of the stations have well maintained Stevenson's screens, while about 30\% of the stations duplicate functions. Only the synoptic station produced the highest quality of information because of the purpose it was meant to serve which is forecasting of weather.

Apart from this, $75 \%$ of the climatic stations have been upgraded by the government to agrometeorological stations. About 63\% of the agrometeorological stations have at least one sophisticated self-recording equipment. Rainfall stations located in secondary schools and government ministries do not take record during holiday. It was observed that $60 \%$ of the rainfall stations were improperly placed, and with records taken by non-professionals. Many of the hydrological stations still take record of river stage in feet and inches which may allow for errors in comparison with the metric system. This observation was made in similar study by Oguntoyinbo (1987) in Southwestern Nigeria. Due to sand mining on riverbeds, some of the staff gauges are either missing, defaced or dislocated, and needs replacement. Most of the stations with automatic equipment especially automatic rainguages have no recording papers. Also that $40 \%$ have damaged equipment which have not been replaced. All the stations depend on the Nigeria Meteorological Services, Oshodi, Lagos for help and assistance which are not forthcoming. It was also observed that sensitized cards or papers for sunshine recorders are in short supply, and over $90 \%$ of the 30 stations studied required interpolation, $60 \%$ of the original data were missing. And finally, about $25 \%$ of the stations studied did not have proper record keeping and retrieving system, and $90 \%$ of the stations are manned by non-professionals (that is, part-time observers). Oguntoyinbo's (1987) study has also shown that most of the stations in Southwestern Nigeria are grossly inefficient in terms of their utilitarian values as a large number of the stations fall short of the internationally standard.

Conclusion: The study has examined the content analysis of hydro-meteorological networks in the Lower River Benu Basin and its implications for agricultural planning. Out of a total of 30 hydrometeorological stations studied in the river basin, results show that complete data are very hard to come by, and so much interpolation had to be done. Also that important hydro-meteorological information relevant for food production and security were missed. The study concludes that there is need to improve the quality of the network by addressing some of the problems already identified in order to ensure sustainable agricultural production in the region.

\section{REFERENCES}

Cattera, J W (1972) An Apriori Model to Sugest Rain Guage Domain. Area Vol. 14.

Cisleriora, J A; Scherzer, W; Hutchinson, P. (1974) The Redesign of Rain Guage Network in Zambia. Hydrological Science Bulleting XIX Vol. 4.

Dawdy, D R; Moss, M E; Matalas, N C 1972 Application of Systems Analysis to Network Design W. M. O Publications.

Dawdy, D R (1972) The Worth of Hydrological Data. Water Resources Research, Vol. 15, No. 6.

Hershfield, D M (1967) On the spacing of rainguage. Symposium on the Design of Hydrological Networks. Publication No. 67 Hydrological Publication No. 67 Hutchinson, P (1969) Estimation of Rainfall in Sparsely Guaged Areas. Bulletin International Association for Hydrological Science XIV, No. 2

Kreuder, W L (1979). Development of Hydrometeorological Networks in British Columbia. Water Resources Research Bol. 15, No. 6

Oguntoyinbo E Y (1987) Information and Content Analysis of Hydrometeorological Networks: A case study of the Ogun-Oshun River Basin in Nigeria. Unpublished M.Sc thesis, Department of Geography, University of Ibadan.

Osborne, H.B and Keppel, R V (1965). Dense Rainguage Network as a Supplement to Regional Network in Semi-arid Regions. Symposium on the Design of Hydrological Networks, Part II Quebec. International Association of Hydrological Science Publication No. 68.

Sharon, D 1972 Spatial Analysis of Rainfall Data from Dense Network. Bulletin International Association of Hydrological Science, Vol. XVII, No. 3. 